\author{
Magdalena Wiśniewska ${ }^{1,2}$, Jan Styczyński ${ }^{2}$, Krzysztof Czyżewski $^{2}$, Monika Pogorzała ${ }^{2}$, Małgorzata Kubicka ${ }^{2}$, \\ Beata Kołodziej ${ }^{2}$, Beata Kuryło-Rafińska², Mariusz Wysocki ${ }^{2}$
}

\title{
IN VITRO DRUG RESISTANCE IN CHILDHOOD MATURE B-CELL ACUTE LYMPHOBLASTIC LEUKEMIA
}

\section{OPORNOŚĆ IN VITRO NA CYTOSTATYKI W OSTREJ BIAŁACZCE LIMFOBLASTYCZNEJ B-KOMÓRKOWEJ U DZIECI}

\author{
${ }^{1}$ Department of Chemotherapy, Oncology Center, Bydgoszcz \\ ${ }^{2}$ Department of Pediatric Hematology and Oncology \\ Collegium Medicum in Bydgoszcz, Nicolaus Copernicus University \\ Head: prof. dr hab. n. med. Mariusz Wysocki
}

Su m mary

B ackground. Mature B-cell acute lymphoblastic leukemia (B-ALL) is a rare type of leukemia in children and counts for $1-2 \%$ of all leukemia cases. Pediatric B-ALL is treated according to protocols for non-Hodgkin lymphomas.

$\mathrm{Objective.} \mathrm{The} \mathrm{aim} \mathrm{of} \mathrm{the} \mathrm{study} \mathrm{was} \mathrm{to} \mathrm{analyze} \mathrm{the}$ in vitro drug resistance in children with B-ALL compared to ALL with other phenotypes.

Material and methods. A total number of 15 children with B-ALL (6 girls and 9 boys, median age 8 years, range 1.9-15 years) were included into the analysis. The in vitro drug resistance tests on leukemic cells were performed by means of the MTT assay. The results of B-ALL patients were compared to those obtained in patients with pre-
B/common ALL (479 cases), pro-B-ALL (31 cases) and T-ALL (87 cases). Results: B-ALL cells were more resistant than pre-B/common-ALL cells to dexamethasone and idarubicin. In comparison to pro-B-ALL phenotype, B-ALL blasts were more resistant to idarubicin and more sensitive to treosulfan. No significant differences were found in the in vitro drug resistance between B-ALL and T-ALL. Blasts of T-ALL were more resistant than pre-B/common-ALL cells to most of tested drugs. Conclusion: From the clinical point of view, B-ALL cells have similar in vitro drug sensitivity when compared to T-ALL, and higher drug resistance to dexamethasone than pre-B/common-ALL.

\section{Streszczenie}

Pomimo znacznej liczby publikacji poświęconych oporności in vitro na cytostatyki $\mathrm{u}$ dzieci $\mathrm{z}$ ostrymi białaczkami, brakuje jakichkolwiek danych o komórkach ostrej białaczki limfoblastycznej z dojrzałych limfocytów B. Jest to najrzadsza postać ostrej białaczki limfoblastycznej u dzieci i obejmuje ok. 1-2\% wszystkich rozpoznań. Białaczkę tę jest leczy się według odrębnych protokołów, wspólnych dla B-ALL i B-NHL.

Celem pracy była analiza oporności in vitro na cytostatyki $\mathrm{w}$ B-ALL $\mathrm{w}$ porównaniu $\mathrm{z}$ komórkami ALL o innych fenotypach: pro-B ALL, pre-B/common ALL i TALL. Do badania włączono 15 pacjentów (6 dziewczynek i 9 chłopców, mediana wieku 8 lat, zakres od 1,9 do 15 lat) z ALL z dojrzałych limfocytów B. Wyniki oporności in vitro porównywano z komórkami chorych z pre-B/common ALL (479 chorych), pro-B ALL (31 chorych) i T-ALL (87 pacjentów). Badania prowadzono $\mathrm{w}$ warunkach in vitro Z wykorzystaniem komórek białaczkowych pobranych i wyizolowanych od pacjenta ze szpiku kostnego i/lub krwi obwodowej w momencie rozpoznania białaczki. Badania wrażliwości i oporności na leki przeprowadzono za pomocą testu MTT. Blasty B-ALL były bardziej oporne niż blasty pre-B/common ALL na deksametazon i idarubicynę. Komórki B-ALL w porównaniu z blastami pro-B ALL bardziej oporne na idarubicynę $i$ bardziej wrażliwe na treosulfan. Pomiędzy komórkami B-ALL i T-ALL nie stwierdzono różnic $\mathrm{w}$ zakresie oporności na badane leki. Dzięki przeprowadzonym badaniom poszerza się wiedza o dziecięcej B-ALL. Być może w protokołach terapeutycznych znajdą zastosowanie leki, dla których wykazano największą wrażliwość in vitro komórek B-ALL, na przykład treosulfan.

Key words: B-ALL, acute B-cell leukemia, in vitro drug resistance, children

Stowa kluczowe: : B-ALL, ostra białaczka B-komórkowa, oporność in vitro na cytostatyki, dzieci 


\section{INTRODUCTION}

Acute leukemias are malignancies characterized by clonal growth of immature cells of hematopoietic origin not subject to regulatory processes and therefore resulting in impairment of regular bone marrow activity and expulsion of normal cells [1]. Acute leukemias are divided into two main types: lymphoblastic and non-lymphoblastic (myeloblastic). Each type includes several subtypes according to morphologic, cytochemical, immunological, genetic and molecular features of leukemic clone [2]. The division of acute leukemias is based on ontogenetical development of hematopoietic system. Leukemias are classified according to the dominant cell line [2,3]. Immunological classification of acute lymphoblastic leukemias (ALL) is presented in Table 1.

Table 1. Immunological classification of acute lymphoblastic leukemias [2]

\begin{tabular}{|l|c|c|c|c|l|}
\hline Subtype & Tdt & HLA-DR & $\begin{array}{c}\text { Cytoplasmatic } \\
\text { Ig }\end{array}$ & $\begin{array}{c}\text { Cell } \\
\text { membran } \\
\text { e Ig }\end{array}$ & $\begin{array}{l}\text { Cellular } \\
\text { differentiation } \\
\text { antigens }\end{array}$ \\
\hline Null & + & + - & - & - & CD34 \\
\hline Pre-pre-B & + & + & - & - & $\begin{array}{l}\text { CD34, cyCD79a, } \\
\text { CD19, CD22 }\end{array}$ \\
\hline Common & + & + & - & - & $\begin{array}{l}\text { cyCD79a, CD19, } \\
\text { CD22, CD10 }\end{array}$ \\
\hline Pre-B & + & + & + & - & $\begin{array}{l}\text { cyCD79a, CD19, } \\
\text { CD22, CD10 }\end{array}$ \\
\hline B-cell & - & - & - & + & $\begin{array}{l}\text { cyCD79a, CD19, } \\
\text { CD22 (CD10), } \\
\text { CD37, CD20 }\end{array}$ \\
\hline Pro/pre-T & + & +- & - & - & $\begin{array}{l}\text { CD7, cyCD3, } \\
\text { (DD2, CD5) }\end{array}$ \\
\hline Tymocyte-T & + & - & - & - & $\begin{array}{l}\text { CD7, cyCD3, } \\
\text { CD2, CD5, CD1, } \\
\text { (TCR-CD3, CD10, } \\
\text { CD4/8) CDCD3, }\end{array}$ \\
\hline T-cell & + & - & - & - & $\begin{array}{l}\text { CD7, CD2, CD5, TCR- } \\
\text { CD3, (CD4/CD8) }\end{array}$ \\
\hline
\end{tabular}

cy - cytoplasmatic, Ig - immunoglobulines, TdT - terminal deoxynucleotidyl transferase

ALL is treated by chemotherapy and radiotherapy. One of the most important factors limiting the progress of efficacy of chemotherapy is development of drug resistant malignant cells. Problem of drug resistance appeared with the introduction of the first cytostatic drug - aminopterin [4].

Despite many publications dedicated to in vitro drug resistance in childhood acute leukemias, resistance of leukemic cells in B-cell acute lymphoblastic leukemia (B-ALL) still remains to be explored. B-ALL is a rare type of leukemia in children and counts for $1-2 \%$ of all leukemia cases. Pediatric BALL is being treated according to protocols for B-cell non-Hodgkin lymphomas. The similar approach to these two malignancies results from the presence of identical type of malignant cells. No study are available which determine in vitro drug resistance in mature B-cell ALL.

The objective of the study was to analyze the in vitro drug resistance in mature childhood B-ALL, in comparison to the in vitro drug resistance in other phenotypes of pediatric ALL cells.

\section{MATERIAL AND METHODS}

A total number of 15 patients with diagnosis of BALL ( 6 girls and 9 boys, median age 8 years, range 1.9-15 years) were included into the study. In each case diagnosis was made with the use of flow cytometry, by expression of surface immunoglobulines, kappa or lambda chains, HLA-DR, CD19, CD20, or cytoplasmatic expression of CD22. The results of in vitro drug resistance were compared to the results of in vitro drug resistance obtained from patients with preB/common ALL (479 patients), pro-B ALL (31patients) i T-ALL (87 patients).

The study was performed in the in vitro environment on leukemia cells isolated from bone marrow and/or peripheral blood at the time of diagnosis. Analysis of the in vitro drug resistance was performed by means of the MTT assay [5]. Bone marrow aspirates were collected into tubes containing heparin in concentration $15-20 \mathrm{U} / \mathrm{ml}$ of bone marrow. Leukemia cells were isolated from bone marrow aspirates by density gradient (Gradisol L, Aqua Medica, Łódź) and then washed twice with RPMI1640 (Sigma, St Louis, USA). The cells were then subjected to red cell lysis using ammonium chloride lysis buffer. Isolated leukemia cells were suspended in culture medium in concentration $2.0 \times 10^{6}$ cells $/ \mathrm{ml}$. Drugs used in the tests were the number of cytotoxic drugs including those used in treatment of de novo and relapsed acute lymphoblastic and nonlymphoblastic leukemias. In this study, the term ,cytotoxic drugs" also refers to prednisolone and dexamethasone used in treatment of acute lymphoblastic leukemia. Active forms of cyclophosphamide and ifosfamide were used, i.e. 4-hydroperoxy-cyclophosphamide and 4-hydroperoxy-ifosfamide. The list of cytotoxic drugs used in the study along with their concentrations is presented in Table 2. The study was performed with the agreement of the Local Bioethical Committee. 
Table 2. Drugs and their concentrations used in the testing of in vitro drug resistance profile

\begin{tabular}{|l|c|}
\hline Drug & Concentrations \\
\hline Prednisolone (Jelfa, Jelenia Góra) & $0.076-250 \mu \mathrm{g} / \mathrm{ml}$ \\
\hline Dexamethasone (Jelfa, Jelenia Góra) & $0.0002-6 \mu \mathrm{g} / \mathrm{ml}$ \\
\hline Idarubicin (Farmitalia, Milan) & $0.002-2 \mu \mathrm{g} / \mathrm{ml}$ \\
\hline Daunorubicin (Rhone-Poulenc-Rhorer) & $0.002-2 \mu \mathrm{g} / \mathrm{ml}$ \\
\hline Doxorubicin (Farmitalia, Milan) & $0.045-8 \mu \mathrm{g} / \mathrm{ml}$ \\
\hline Mitoxantrone (Jelfa, Jelenia Góra) & $0.01-1 \mu \mathrm{g} / \mathrm{ml}$ \\
\hline Vincristine (Eli-Lilly, Indianapolis) & $0.0195-20 \mu \mathrm{g} / \mathrm{ml}$ \\
\hline $\begin{array}{l}\text { Etoposide (Vepesid, Bristol-Myers Squibb, } \\
\text { Princeton) }\end{array}$ & $0.048-50 \mu \mathrm{g} / \mathrm{ml}$ \\
\hline L-asparaginase (Medac, Hamburg) & $0.0032-10 \mathrm{IU} / \mathrm{ml}$ \\
\hline Cytarabine (Cytosar, Pharmacia \& Upjohn) & $0.0098-10 \mu \mathrm{g} / \mathrm{ml}$ \\
\hline Fludarabine (Fludara, Schering AG, Berlin) & $0.019-20 \mu \mathrm{g} / \mathrm{ml}$ \\
\hline Cladribine (Biodribin, Bioton, Warszawa) & $0.001-40 \mu \mathrm{g} / \mathrm{ml}$ \\
\hline 6-Thioguanine (Sigma, nr A4882) & $1.5625-50 \mu \mathrm{g} / \mathrm{ml}$ \\
\hline Melphalan (Alkeran, Glaxo Wellcome, Parma) & $0.039-40 \mu \mathrm{g} / \mathrm{ml}$ \\
\hline $\begin{array}{l}\text { Cyclophosphamide } \\
\text { Cyclophosphamide, Asta Medica, Hamburg) }\end{array}$ & $0.097-100 \mu \mathrm{g} / \mathrm{ml}$ \\
\hline $\begin{array}{l}\text { Ifosfamide (4-HOO-Ifosfamide, Asta Medica, } \\
\text { Hamburg) }\end{array}$ & $0.0977-100$ \\
\hline Treosulfan (Ovastat, Medac, Hamburg) & $0.00001-1.0$ \\
\hline \multicolumn{2}{|c|}{$\mu \mathrm{gl} / \mathrm{ml}$} \\
\hline Thiotepa (Lederle, Riemser, Greifswald) & $0.032-100 \mu \mathrm{g} / \mathrm{ml}$ \\
\hline
\end{tabular}

For the MTT assay the following validity criteria were used: (a) samples only with at least of $90 \%$ of blasts were tested and (b) samples only with at least $70 \%$ of blasts at the end of incubation were included in further analysis. Optical density testing in control sample had to exceed value 0.050 .

Statistical analysis: In vitro drug resistance in analyzed groups was presented as median and range of the LC50 index value for each drug. In order to compare relative in vitro drug resistance between two analyzed groups, parameter of relative resistance (RR) was used, as a ratio of LC50 median value for tested drug in one group to LC50 median value for this drug in the other group. The value $R R<1$ indicates better sensitivity to the tested drug and $\mathrm{RR}>1$ indicates higher drug resistance. The Mann-Whitney $U$ test was performed to compare differences between groups. In all analyses p-values <0.05 were regarded significant and p-value was determined based on two-sided test. Statistical analysis was performed with SPPS21 software.

\section{RESULTS}

Significant differences in the in vitro drug resistance in B-ALL compared to other ALL phenotypes have been determined (Table 3). The BALL blasts were more resistant than pre-B/commonALL cells to dexamethasone $(\mathrm{RR}=19.3, p=0.038)$ and idarubicin $(\mathrm{RR}=2.2, \quad p=0.025)$. No significant differences were found in the in vitro drug resistance between B-ALL and T-ALL cells. B-ALL cells, as compared to pro-B-ALL cells were more resistant to idarubicin ( $\mathrm{RR}=2.5, p=0.037)$ and more sensitive to treosulfan $(\mathrm{RR}=0.15, p=0.05)$. Compared to pre$\mathrm{B} /$ common-ALL cells, blasts of pro-B-ALL were significantly more in vitro resistant to treosulfan ( $\mathrm{RR}=10, p=0.011)$ and cyclophosphamide ( $\mathrm{RR}=1.9$, $p=0.047)$. The test showed significant differences in in vitro drug resistance between T-ALL and pro-B-ALL cells for following drugs: $(\mathrm{RR}=1.6, \quad p=0.025)$, etoposide $(\mathrm{RR}=3.4, p=0.037)$, fludarabine $(\mathrm{RR}=7$, $p=0.004)$ and cladribine $(\mathrm{RR}=43, p=0.003)$ and borderline significance to vincristine $(R R=1.99$, $p=0.051$ ). Blasts of T-ALL were more resistant than pre-B/common-ALL cells to most of tested drugs. Statistical significance was shown for prednisolone $(\mathrm{RR}=5.2, \quad p=0.002), \quad$ dexamethasone $\quad(\mathrm{RR}=12.8$, $p=0.036)$, daunorubicin $(\mathrm{RR}=1.2, p=0.018)$, epirubicin $(\mathrm{RR}=2.3, p=0.009)$, vincristine $(\mathrm{RR}=2.4, p<0.001)$, etoposide $(\mathrm{RR}=1.7, p=0.001), \mathrm{L}$-asparaginase $(\mathrm{RR}=2.7$, $p<0.001)$, cytarabine ( $\mathrm{RR}=1.8, p=0.028)$, fludarabine $(\mathrm{RR}=5.7, p<0.001)$, cladribine $(\mathrm{RR}=17.2, p=0.003)$, nelarabine $(\mathrm{RR}=5.2, p=0.036)$, clofarabine $(\mathrm{RR}=13$, $p=0.009)$ and thiotepa $(\mathrm{RR}=2.1, p=0.006)$.

Table 3. Comparison of values of in vitro drug resistance to tested drugs in different ALL phenotypes

\begin{tabular}{|c|c|c|c|c|}
\hline \multirow[t]{2}{*}{ Drug } & \multicolumn{4}{|c|}{ Median and quartiles of LC50 } \\
\hline & $\begin{array}{l}\text { B-ALL } \\
(\mathrm{n}=15)\end{array}$ & $\begin{array}{c}\text { pre-B/common } \\
\text { ALL }(n=479)\end{array}$ & $\begin{array}{c}\text { pro-B ALL } \\
(\mathbf{n}=31)\end{array}$ & $\begin{array}{l}\text { T-ALL } \\
(\mathrm{n}=87)\end{array}$ \\
\hline Prednisolone & $\begin{array}{l}90.98(\mathrm{n}=10) \\
45.10-160.92\end{array}$ & $\begin{array}{c}12.26(\mathrm{n}=353) \\
0.69-109.91\end{array}$ & $\begin{array}{l}15.63(\mathrm{n}=27) \\
2.96-111.90\end{array}$ & $\begin{array}{r}64.62(\mathrm{n}=75) \\
3.40-138.01\end{array}$ \\
\hline Dexamethasone & $\begin{array}{c}6.0(\mathrm{n}=7) \\
6.0-6.0\end{array}$ & $\begin{array}{c}0.31(\mathrm{n}=170) \\
0.02-6.0\end{array}$ & $\begin{array}{c}3.17(\mathrm{n}=10) \\
0.20-6.0\end{array}$ & $\begin{array}{c}3.98(\mathrm{n}=29) \\
0.11-6.0\end{array}$ \\
\hline Idarubicin & $\begin{array}{c}0.35(\mathrm{n}=9) \\
0.23-2.0\end{array}$ & $\begin{array}{c}0.16(\mathrm{n}=274) \\
0.06-0.43\end{array}$ & $\begin{array}{c}0.14(\mathrm{n}=23) \\
0.02-0.37\end{array}$ & $\begin{array}{c}0.23(\mathrm{n}=59) \\
0.07-0.50\end{array}$ \\
\hline Daunorubicin & $\begin{array}{c}0.34(\mathrm{n}=10) \\
0.22-1.87\end{array}$ & $\begin{array}{c}0.24(\mathrm{n}=351) \\
0.09-0.46\end{array}$ & $\begin{array}{c}0.19(\mathrm{n}=27) \\
0.07-0.37\end{array}$ & $\begin{array}{c}0.30(\mathrm{n}=75) \\
0.15-1.10\end{array}$ \\
\hline Doxorubicin & $\begin{array}{c}1.25(\mathrm{n}=5) \\
0.90-8.0\end{array}$ & $\begin{array}{c}1.22(\mathrm{n}=230) \\
0.58-8.0\end{array}$ & $\begin{array}{c}.33(\mathrm{n}=19) \\
0.54-8.0\end{array}$ & $\begin{array}{c}1.29(\mathrm{n}=60) \\
0.63-8.0\end{array}$ \\
\hline Mitoxantrone & $\begin{array}{c}0.37(\mathrm{n}=5) \\
0.12-0.76\end{array}$ & $\begin{array}{c}0.08(\mathrm{n}=224) \\
0.03-0.36\end{array}$ & $\begin{array}{c}0.03(\mathrm{n}=19) \\
0.02-0.31\end{array}$ & $\begin{array}{c}0.13(\mathrm{n}=51) \\
0.03-0.45\end{array}$ \\
\hline Vincristine & $\begin{array}{l}5.15(\mathrm{n}=10) \\
1.50-13.06\end{array}$ & $\begin{array}{c}1.19(\mathrm{n}=356) \\
0.26-4.28\end{array}$ & $\begin{array}{c}1.46(\mathrm{n}=27) \\
0.14-3.73\end{array}$ & $\begin{array}{c}2.91(\mathrm{n}=76) \\
0.80-7.29\end{array}$ \\
\hline Etoposide & $\begin{array}{c}13.75(\mathrm{n}=10) \\
0.88-25.44\end{array}$ & $\begin{array}{c}1.67(\mathrm{n}=337) \\
0.62-9.40\end{array}$ & $\begin{array}{c}0.84(\mathrm{n}=25) \\
0.59-11.57\end{array}$ & $\begin{array}{c}2.90(\mathrm{n}=70) \\
1.09-50.0\end{array}$ \\
\hline L-asparaginase & $\begin{array}{c}1.17(\mathrm{n}=11) \\
0.38-10.0\end{array}$ & $\begin{array}{c}0.33(\mathrm{n}=351) \\
0.06-1.47\end{array}$ & $\begin{array}{c}0.66(\mathrm{n}=25) \\
0.13-1.14\end{array}$ & $\begin{array}{c}0.90(\mathrm{n}=76) \\
0.23-10.0\end{array}$ \\
\hline Cytarabine & $\begin{array}{c}0.73(\mathrm{n}=10) \\
0.25-10.0\end{array}$ & $\begin{array}{c}0.66(\mathrm{n}=271) \\
0.29-1.82\end{array}$ & $\begin{array}{c}0.47(\mathrm{n}=23) \\
0.21-2.50\end{array}$ & $\begin{array}{c}1.20(\mathrm{n}=53) \\
0.40-6.03\end{array}$ \\
\hline Fludarabine & $\begin{array}{l}0.84(\mathrm{n}=5) \\
0.38-15.23\end{array}$ & $\begin{array}{c}0.39(\mathrm{n}=225) \\
0.18-1.63\end{array}$ & $\begin{array}{c}0.32(\mathrm{n}=18) \\
0.16-5.77\end{array}$ & $\begin{array}{c}2.24(\mathrm{n}=54) \\
0.75-9.45\end{array}$ \\
\hline Cladribine & $\begin{array}{l}0.08(n=8) \\
0.03-30.04\end{array}$ & $\begin{array}{c}0.05(\mathrm{n}=217) \\
0.02-1.28\end{array}$ & $\begin{array}{c}0.02(\mathrm{n}=18) \\
0.01-0.69\end{array}$ & $\begin{array}{c}0.86(\mathrm{n}=46) \\
0.03-16.53\end{array}$ \\
\hline 6-Thioguanine & $\begin{array}{l}8.46(\mathrm{n}=6) \\
2.18-29.75\end{array}$ & $\begin{array}{c}5.72(\mathrm{n}=221) \\
3.08-15.46\end{array}$ & $\begin{array}{c}7.47(\mathrm{n}=19) \\
5.20-50.0\end{array}$ & $\begin{array}{l}5.39(\mathrm{n}=53) \\
2.70-18.36\end{array}$ \\
\hline Melphalan & $\begin{array}{l}8.99(\mathrm{n}=5) \\
2.37-25.63\end{array}$ & $\begin{array}{c}3.02(\mathrm{n}=151) \\
1.10-8.20\end{array}$ & $\begin{array}{c}2.27(\mathrm{n}=14) \\
0.83-15.60\end{array}$ & $\begin{array}{c}5.78(\mathrm{n}=45) \\
1.16-17.97\end{array}$ \\
\hline Cyclophosphamide & $\begin{array}{c}0.39(\mathrm{n}=5) \\
0.31-0.92\end{array}$ & $\begin{array}{c}0.60(\mathrm{n}=156) \\
0.26-1.23\end{array}$ & $\begin{array}{l}1.15(\mathrm{n}=19) \\
0.39-19.84\end{array}$ & $\begin{array}{c}0.78(\mathrm{n}=42) \\
0.41-2.15\end{array}$ \\
\hline Ifosfamide & $\begin{array}{l}6.07(\mathrm{n}=5) \\
131-58.19\end{array}$ & $\begin{array}{c}4.91(\mathrm{n}=82) \\
1.55-16.59\end{array}$ & $\begin{array}{l}9.38(\mathrm{n}=5) \\
2.98-61.50\end{array}$ & $\begin{array}{c}5.82(\mathrm{n}=21) \\
3.04-16.45\end{array}$ \\
\hline Treosulfan & $\begin{array}{c}0.15(\mathrm{n}=5) \\
0.0002-0.66\end{array}$ & $\begin{array}{c}0.10(\mathrm{n}=185) \\
0.01-1.0\end{array}$ & $\begin{array}{c}1.00(\mathrm{n}=16) \\
0.23-1.0\end{array}$ & $\begin{array}{c}1.00(\mathrm{n}=53) \\
0.03-1.0\end{array}$ \\
\hline Thiotepa & $\begin{array}{l}1.49(\mathrm{n}=5) \\
1.08-50.76\end{array}$ & $\begin{array}{c}0.97(\mathrm{n}=185) \\
0.32-3.25\end{array}$ & $\begin{array}{c}0.71(\mathrm{n}=17) \\
0.28-4.78\end{array}$ & $\begin{array}{c}2.06(\mathrm{n}=52) \\
0.81-8.78\end{array}$ \\
\hline
\end{tabular}

The values are presented in following units: IU/ml for Lasparaginase, $\mu \mathrm{g} / \mathrm{ml}$ for the rest of the drugs. $\mathrm{n}-$ the number of patients 


\section{DISCUSSION}

In this study we analyzed the in vitro drug resistance in children with B-ALL, rare type of leukemia in childhood and compared it to other ALL phenotypes: pro-B ALL, pre-B/common ALL and TALL. We found that blasts of mature B-ALL were more resistant to dexamethasone and idarubicin than pre-B/common ALL cells. We found also that B-ALL cells compared to pro-B ALL blasts were more resistant to idarubicin and more sensitive to treosulfan. No significant statistical differences were discovered in the in vitro drug resistance between B-ALL and TALL cells. Significant differences were shown in the resistance to treosulfan and cyclophosphamide between pro-B and pre-B/common ALL blasts. Significant differences were found between T-ALL and pro-B ALL in in vitro resistance to daunorubicin, etoposide, fludarabine, cladribine, while borderline statistical significance was determined in case of vincristine. Blasts of T-ALL were more resistant than preB/common ALL cells to most of tested drugs.

In the study of Pieters et al., it was shown that TALL blasts are more resistant than pre-B ALL cells to prednisolone, daunorubicin, L-asparaginase, cytarabine and 6-thioguanine [6]. In our previous analyses, it was shown that common-ALL cells were more sensitive than T-ALL cells to most tested drugs, probably except from 6-thioguanine and ifosfamide [7], and that pre$\mathrm{B} /$ common ALL were more sensitive to Lasparaginase, vincristine, alkylating agents and prednisolone, when compared to T-ALL cells [8]. In another study, no significant differences were discovered in the in vitro drug resistance to daunorubicin, mitoxantrone and 6-thioguanine between T-ALL and pre-B/common ALL cells, but it was shown that T-ALL cells were more sensitive to bortezomib [9].

In our study, B-ALL blasts had similar in vitro drug resistance to tested drugs as T-ALL cells. T-ALL blasts were more resistant to most tested drugs than pre$\mathrm{B} /$ common-ALL. This presumably has significant impact on results of the treatment since B-ALL, as well as T-ALL have worse prognosis when compared to pre-B/common-ALL in children.

Cellular drug resistance is one of the main causes of the frequent ultimate failure of chemotherapy in childhood acute leukemias [10], especially on relapse [11-12]. Current concepts suggest that drug resistance is related to the presence of leukemic stem cells [1314].

From the clinical point of view, results of our study show that B-ALL is the subtype of leukemia characterized by in vitro drug resistance similar to T-ALL and more resistant to dexamethasone than pre$\mathrm{B} /$ common-ALL. The other conclusion from our study is that B-ALL is relatively sensitive to treosulfan in the in vitro conditions; however, this drug is not used in therapy of acute leukemias.

\section{ACKNOWLEDGEMENTS}

Authors wish to thank following collaborators from other pediatric hematology and oncology centers in Poland for sending patients material and clinical data: prof. dr. hab. n. med. Michał Matysiak and dr hab. n. med. Iwona Malinowska from Department of Pediatric Hematology and Oncology, Medical University, Warszawa; prof. dr hab. n. med. Walentyna Balwierz and lek. med. Edyta Juraszewska from Department of Pediatric Hematology Collegium Medicum UJ, Kraków; prof. dr hab. n. med. Jacek Wachowiak and dr n. med. Benigna Konatkowska from Department of Pediatric Hematology, Oncology and Transplantology, Medical University, Poznań; dr n. med. Maria Wieczorek and dr n. med. Igor Olejnik from Division of Hematology and Oncology, Pediatric Center, Chorzów; prof. dr hab. n. med. Maryna KrawczukRybak and dr n. med. Marta Kuźmicz from Department of Pediatric Oncology Medical University, Białystok; prof. dr hab. n. med. Jerzy Kowalczyk and dr n. med. Maria Jolanta Stefaniak from Department of Pediatric Hematology and Oncology, Medical University, Lublin; dr n. med. Wanda Badowska from Division of Pediatric Hematology and Oncology, Children Hospital, Olsztyn; prof. dr hab. n. med. Tomasz Szczepański and $\mathrm{dr} \mathrm{n}$. med. Renata Tomaszewska from Department of Pediatric Hematology and Oncology, Medical University, Zabrze; prof. dr hab. n. med. Elżbieta AdamkiewiczDrożyńska and dr n. med. Lucyna MaciejkaKapuścińska from Department of Pediatric Hematology and Oncology Medical University, Gdańsk; dr n. med. Grażyna Sobol and dr n. med. Agnieszka Mizia-Malarz from Division of Pediatric Hematology and Oncology, Department of Pediatrics, Medical University, Katowice. 


\section{REFERENCES}

1. Balwierz W. Ostra białaczka szpikowa. In: Chybicka A, Sawicz-Birkowska K (eds): Onkologia i hematologia dziecięca, Edition Warszawa: Wydawnictwo Lekarskie PZWL 2008; 220-242.

2. Hołowiecki J. Białaczki ostre. In: Dmoszyńska A, Robak T (eds): Podstawy hematologii, Edition Lublin: Czelej 2008; 251-288.

3. Niemeyer C, Sallan S. Acute lymphoblastic leukemia. In: Nathan D, Oski F (eds): Hematology of Infancy and Childhood 4th Edition, Edition Philadelphia: W. B. Saunders Company 1992; 1249-1287.

4. Farber S, Diamond L, Mercer R. Temporary remission in acute leukemia in children produced by folic acid antagonist, 4-aminopteroyl-glutamic acid (aminopterin). N Engl J Med 1948; 238: 788-793.

5. Pieters R, Huismans DR, Leyva A, Veerman AJ. Adaptation of the rapid automated tetrazolium dye based (MTT) assay for chemosensitivity testing in childhood leukemia. Cancer Lett 1988; 41: 323-332.

6. Pieters R, Kaspers GJ, van Wering ER et al. Cellular drug resistance profiles that might explain the prognostic value of immunophenotype and age in childhood acute lymphoblastic leukemia. Leukemia 1993; 7: 392-397.

7. Styczyński J, Kołodziej B, Rafińska B et al. Skojarzony profil oporności in vitro na cytostatyki $\mathrm{w}$ ostrej białaczce limfoblastycznej u dzieci de novo i we wznowie: związek $\mathrm{z}$ cyklem komórkowym i rearanżacjami genów. Współcz Onkol 2007; 11: 367 375.

8. Wysocki M, Styczyński J, Dębski R et al. Drug resistance profile in childhood acute lymphoblastic leukemia on diagnosis and at relapse with respect to percentile values. Acta Haematol Pol 2002; 33: 341349.

9. Szczepanek J, Pogorzała M, Konatkowska B et al. Differential ex vivo activity of bortezomib in newly diagnosed paediatric acute lymphoblastic and myeloblastic leukaemia. Anticancer Res 2010; 30: 2119-2124.
10. Styczyński J. Drug resistance in childhood acute myeloid leukemia. Curr Pharm Biotechnol, 2007; 8: 59-75.

11. Kuryło-Rafińska B, Kołodziej B, Kubicka M, Wysocki M, Styczyński J. Differential ex vivo drug resistance profile in first and subsequent relapsed childhood acute myeloid leukemia in comparison to initial diagnosis. Med Biol Sci, 2012; 26: 47-52.

12. Styczynski J, Wysocki M. Ex vivo drug resistance in childhood acute myeloid leukemia on relapse is not higher than at first diagnosis. Pediatric Blood and Cancer, 2004; 42: 195-199.

13. Drewa T, Styczyński J, Szczepanek J. Is the cancer stem cell population a "player" in multi-drug resistance? Acta Pharm Pol, 2008; 65: 493-500.

14. Styczyński J, Drewa T. Leukemic stem cells: from metabolic pathways and signaling to new concept of drug resistance targeting. Acta Biochim Pol; 2007; 54 : 717-726.

Address for correspondence:

Jan Styczyński

Katedra Pediatrii, Hematologii i Onkologii, ul. Skłodowskiej-Curie 9,

85-094 Bydgoszcz,

e-mail: jstyczynski@cm.umk.pl

tel: (52) 5854860

fax: (52) 5854867

Received: 14.02.2014

Accepted for publication: 6.05.2014 